\title{
Non coding RNAs as the critical factors in chemo resistance of bladder tumor cells
}

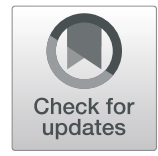

\author{
Amir Sadra Zangouei ${ }^{1}$, Hamid Reza Rahimi ${ }^{2}$, Majid Mojarrad ${ }^{2}$ and Meysam Moghbeli $2^{2^{*}}$ (D)
}

\begin{abstract}
Background: Bladder cancer ( $\mathrm{BCa}$ ) is the ninth frequent and 13th leading cause of cancer related deaths in the world which is mainly observed among men. There is a declining mortality rates in developed countries. Although, the majority of BCa patients present Non-Muscle-Invasive Bladder Cancer (NMIBC) tumors, only $30 \%$ of patients suffer from muscle invasion and distant metastases. Radical cystoprostatectomy, radiation, and chemotherapy have proven to be efficient in metastatic tumors. However, tumor relapse is observed in a noticeable ratio of patients following the chemotherapeutic treatment. Non-coding RNAs (ncRNAs) are important factors during tumor progression and chemo resistance which can be used as diagnostic and prognostic biomarkers of BCa.

Main body: In present review we summarized all of the IncRNAs and miRNAs associated with chemotherapeutic resistance in bladder tumor cells.

Conclusions: This review paves the way of introducing a prognostic panel of ncRNAs for the BCa patients which can be useful to select a proper drug based on the IncRNA profiles of patients to reduce the cytotoxic effects of chemotherapy in such patients.
\end{abstract}

Keywords: Bladder cancer, LncRNA, MiRNA, Drug resistance, Chemotherapy, Prognosis, Marker

\section{Background}

Bladder cancer $(\mathrm{BCa})$ is the ninth most frequent cancer worldwide with an annual estimated 356,000 new cases and 145,000 deaths [1]. It ranks the fourth common cancer among males [2]. Many factors are involved in $\mathrm{BCa}$ progression such as smoking, industrial carcinogens, and familial history [3]. Approximately $10-20 \%$ of the patients who experience recurrence are prone to develop the muscle-invasive bladder cancer (MIBC) [4]. Although, surgery is the main treatment option of non-invasive bladder cancer, a noticeable ratio of these patients experience tumor relapse [3]. Non-muscle-invasive tumors can be treated by transurethral resection followed by chemotherapy or immunotherapy. Grade of tumor invasion is an important factor for the treatment management in which

\footnotetext{
*Correspondence: moghbelim@mums.ac.ir; Meysam_moghbeli@yahoo.com ${ }^{2}$ Department of Medical Genetics and Molecular Medicine, School of Medicine, Mashhad University of Medical Sciences, Mashhad, Iran Full list of author information is available at the end of the article
}

low-grade tumors are treated with only resection, while high-grade with relapse risk may require further resection and bacille Calmette-Guérin (BCG) therapy [5]. Chemotherapy has been considered as an effective first-line treatment for early $\mathrm{BCa}$ aiming to suppress cancer progression, prevent recurrences, and enhance patients' survival [6]. However, $\mathrm{BCa}$ is prone for the chemo resistance and tumor relapse. Since, early detection can significantly improve the survival rate, monitoring of the drugresistance progression can be helpful for early treatment of recurrence [7]. A combine of chemo radiation and cystectomy, offers an efficient option with long-term survival rates [8]. The methotrexate, vinblastine, doxorubicin, and cisplatin combination therapy was associated with severe side effects, while the Gemcitabine/cisplatin combination is safe and efficient in BCa patients [9]. Cisplatin-based chemotherapy is the common method, however it has not any influence on overall survival following radical cystectomy among high-risk cases [10]. Regarding the

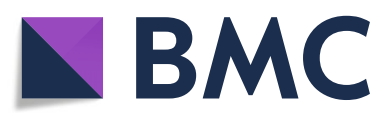

(C) The Author(s). 2020 Open Access This article is licensed under a Creative Commons Attribution 4.0 International License, which permits use, sharing, adaptation, distribution and reproduction in any medium or format, as long as you give appropriate credit to the original author(s) and the source, provide a link to the Creative Commons licence, and indicate if changes were made. The images or other third party material in this article are included in the article's Creative Commons licence, unless indicated otherwise in a credit line to the material. If material is not included in the article's Creative Commons licence and your intended use is not permitted by statutory regulation or exceeds the permitted use, you will need to obtain permission directly from the copyright holder. To view a copy of this licence, visit http://creativecommons.org/licenses/by/4.0/ The Creative Commons Public Domain Dedication waiver (http://creativecommons.org/publicdomain/zero/1.0/) applies to the data made available in this article, unless otherwise stated in a credit line to the data. 
chemotherapeutic resistance, many patients are faced with side effects without any efficient benefit. Genetic factors are associated with drug resistance through regulation of drug efflux, DNA repair, cell cycle, and apoptosis [11-13]. Non-coding RNAs (ncRNAs) are a class of RNAs including long non-coding RNAs (lncRNA), micro RNAs (miRNA), and circular RNAs (circRNA) which are involved in post transcriptional regulation. Since, the ncRNAs have an important role in drug response of tumor cells [14-16], we have summarized all of the reported ncRNAs which have been associated with chemotherapeutic resistance in $\mathrm{BCa}$ for the first time in the world (Table.1).

\section{Main text}

\section{Long non coding RNAs}

LncRNAs are key regulatory molecules involved in cell proliferation, development, and oncogenesis that achieve their roles through post-transcriptional regulation [54]. They have pivotal roles in transcriptional regulation through functioning as molecular signals, sponges, decoys, scaffolds, and enhancer RNAs [55, 56]. Drug resistance in various malignancies can be attributed to lncRNAs function as regulator of gene expression which results in higher rate of tumor cell proliferation and reduced apoptosis [57]. Cisplatin (DDP) has been used among the first-line chemotherapy medications for high grade and stage bladder tumor patients [58]. However, a large fraction of $\mathrm{BCa}$ patients are resistant to cisplatinbased chemotherapy [9, 59]. Sirtuin-1 (SIRT1) is a NAD-dependent deacetylase that diminishes the tumor suppressive effect of p53, thereby dampening the efficacy of clinical radiotherapy and chemotherapy. Therefore, SIRT1 inhibition results in tumor cells death through p53 modulation and activation [60]. It has been reported that there were significant decreased and increased levels of miR-133b and MST1P2 expressions in cisplatinresistant bladder tumor cell lines, respectively. MiR-133b directly suppressed the SIRT1 expression. MST1P2/miR$133 \mathrm{~b}$ axis had an important role in cisplatin-resistance of BCa through SIRT1/p53 pathway [17]. It has been shown that there was overexpression of HIF1A-AS2 in tissues and cell lines of $\mathrm{BCa}$ following the cisplatin treatment which makes bladder tumor cells resistance to cisplatin-triggered cell death. HIF1A-AS2 enhanced survival of tumor cells by upregulating high-mobility group A1 (HMGA1), thereby limiting the transcriptional function of p53 family. It was identified that interaction of p53 with HMGA1 restricted their transcriptional activity on proapoptotic BAX protein [18]. MiR-582-5p has tumor-suppressive functions and reduces the tumor cell proliferation and migration via targeting CDK1, FOXC1, and RAB27a [61-63]. ATG7 is implicated in the two ubiquitin-like systems and is essential for autophagy [64]. It has been reported that the UCA1 was up regulated in $\mathrm{BCa}$. It acts as an endogenous sponge to down regulate the miR-582-5p which resulted in ATG7 over expression. UCA1 is important for the regulation of proliferation and invasion of $\mathrm{BCa}$ cells through modulating UCA1-miR582-5p-ATG7-autophagy axis. As UCA1 shRNA markedly reduced the expression level of LRP, MRP1, and GST, and significantly overexpressed TOPO-II, it is hypothesized that knockdown of UCA1 decreases chemo resistance [19]. It has been observed that there was GAS5 down regulation in bladder transitional cell carcinoma which was associated with advance grade and stage. GAS5 also increased doxorubicin-induced apoptosis through $B C L-2$ suppression [20].

Drug efflux is also another mechanism of tumor drug resistance that can be regulated by different lncRNAs [65]. MALAT1 increases the expression levels of MRP1 an MDR1 through STAT3, thereby is responsible for inducing cisplatin-resistance in lung tumor cells [66]. It has been shown that MALAT1 repression caused a better response of $\mathrm{BCa}$ cells to chemotherapy and increased cisplatin sensitivity. MALAT1 induced chemo resistance through regulating miR-101-3p/VEGFC axis. Bladder tumor tissue had higher level of MALAT1 compared with normal margins [21]. Gastric carcinoma proliferation-enhancing transcript 1 (GHET1) is a IncRNA involved in cisplatin resistance in gastric cancer [67]. MRP1 is a member of ATP-binding cassette $(A B C)$ superfamily which regulates the intracellular distribution of molecules and is also involved in transport of different complexes across extra-and intra-cellular membranes. Moreover, it confers resistance to chemotherapeutic treatments in cancer cells due to its ability of drugs efflux. It has been observed that there was significant GHET1 overexpression in $\mathrm{BCa}$, which was positively correlated with advance tumor grade and muscle invasion. GHET1 up regulation was also associated with higher Gemcitabinechemo resistance in BCa cells. Moreover, GHET1 up regulated the MRP1 in $\mathrm{BCa}$ cells, which in turn enhanced their Gemcitabine resistance [22]. Gemcitabine is a nucleotide analogue commonly used as the first line anticancer drug therapy for many solid tumors such as breast cancer, ovarian cancer, and $\mathrm{BCa}[68,69]$. FOXD2-AS1 is significantly up regulated in $\mathrm{BCa}$, and via establishing a positive feedback loop with AKT and E2F1 is contributed to increased progression and aggressiveness of bladder tumor cells [70]. It has been shown that there was a dosedependent pattern of FOXD2-AS1 overexpression in gemcitabine resistant bladder tumor cells. Repression of FOXD2-AS1 expression resulted in lower levels of $\mathrm{ABCC} 3$ protein, and down regulation of several genes 
Table 1 all of the ncRNAs associated with chemotherapeutic resistance in BCa

\begin{tabular}{|c|c|c|c|c|c|}
\hline Study & Year & Gene & Country & Drug & Results \\
\hline $\begin{array}{l}\text { Chen } \\
{[17]}\end{array}$ & 2020 & $\begin{array}{l}\text { MST1P2, } \\
\text { miR- } \\
\text { 133b }\end{array}$ & China & Cisplatin & $\begin{array}{l}\text { MST1P2/miR-133b axis had an important role in cisplatin-resistance of } \\
\text { bladder cancer through SIRT1/p53 pathway. }\end{array}$ \\
\hline $\begin{array}{l}\text { Chen } \\
{[18]}\end{array}$ & 2019 & $\begin{array}{l}\text { HIF1A- } \\
\text { AS2 }\end{array}$ & China & Cisplatin & HIF1A-AS2 enhances survival of tumor cells by upregulating HMGA1. \\
\hline Wu [19] & 2019 & UCA1 & China & Rapamycin & $\begin{array}{l}\text { UCA1 acts as an endogenous sponge to down regulate the miR-582- } \\
5 p \text { which resulted in ATG7 over expression. }\end{array}$ \\
\hline $\begin{array}{l}\text { Zhang } \\
\text { [20] }\end{array}$ & 2017 & GAS5 & China & Doxorubicin & $\begin{array}{l}\text { GAS5 increased doxorubicin-induced apoptosis through BCL-2 } \\
\text { suppression. }\end{array}$ \\
\hline Liu [21] & 2019 & MALAT1 & China & Cisplatin & $\begin{array}{l}\text { MALAT1 induced chemo resistance through regulating miR-101-3p/ } \\
\text { VEGFC axis. }\end{array}$ \\
\hline Li [22] & 2019 & GHET1 & China & Gemcitabine & GHET1 up regulated the MRP1. \\
\hline An [23] & 2018 & $\begin{array}{l}\text { FOXD2- } \\
\text { AS1 }\end{array}$ & China & Gemcitabine & FOXD2-AS1 indirectly targets the ABCC3 through miR-143 sponging. \\
\hline $\begin{array}{l}\text { Wang } \\
{[24]}\end{array}$ & 2017 & MiR-143 & China & Gemcitabine & $\begin{array}{l}\text { The miR-143 attenuated gemcitabine resistance via IGF-1R } \\
\text { suppression. }\end{array}$ \\
\hline $\begin{array}{l}\text { Fan } \\
{[25]}\end{array}$ & 2014 & UCA1 & China & Cisplatin & UCA1 overexpression was contributed to upregulation of WNT6. \\
\hline $\begin{array}{l}\text { Pan } \\
{[26]}\end{array}$ & 2016 & UCA1 & China & Cisplatin, Gemcitabine & $\begin{array}{l}\text { UCA1 activates miR-196a-5p via CREB which results in gemcitabine/ } \\
\text { cisplatin resistance. }\end{array}$ \\
\hline Xie [27] & 2017 & TUG1 & China & Doxorubicin & $\begin{array}{l}\text { TUG1 knockdown decreased Dox resistance through restraining the } \\
\text { activity of Wnt/ } \beta \text {-catenin pathway. }\end{array}$ \\
\hline Xie [28] & 2018 & $\begin{array}{l}\text { CDKN2B- } \\
\text { AS }\end{array}$ & China & Gemcitabine & CDKN2B-AS induced Gemcitabine-resistance via sponging Let-7. \\
\hline $\begin{array}{l}\text { Zhuang } \\
\text { [29] }\end{array}$ & 2017 & LET & China & Gemcitabine & $\begin{array}{l}\text { TGF } \beta 1 \text { promotes gemcitabine resistance through LncRNA-LET/NF90/ } \\
\text { miR-145 axis. }\end{array}$ \\
\hline Li [30] & 2019 & DLEU1 & China & Cisplatin & DLEU1 up regulated the HS3ST3B1 via miR-99b suppression. \\
\hline $\begin{array}{l}\text { Zhao } \\
\text { [31] }\end{array}$ & 2019 & NEAT1.1 & China & Cisplatin & NEAT1.1 was down regulated following cisplatin treatment. \\
\hline $\begin{array}{l}\text { Xiao } \\
{[32]}\end{array}$ & 2018 & $\begin{array}{l}\text { MiR-22- } \\
3 p\end{array}$ & China & $\begin{array}{l}\text { Paclitaxel, Adriamycin, Epirubicin, } \\
\text { hydroxycamptothecin, Cisplatin, and } \\
\text { Gemcitabine }\end{array}$ & $\begin{array}{l}\text { MiR-22-3p enhanced resistance to chemotherapy in bladder tumor } \\
\text { cells through suppressing NET1. }\end{array}$ \\
\hline $\begin{array}{l}\text { Deng } \\
{[33]}\end{array}$ & 2015 & MiR-27a & China & Paclitaxel, Adriamycin, Cisplatin & MiR-27a/RUNX-1 pathway has a key function in chemo-resistance. \\
\hline $\begin{array}{l}\text { Drayton } \\
{[34]}\end{array}$ & 2014 & MiR-27a & UK & Cisplatin & $\begin{array}{l}\text { MiR-27a deregulation induced cisplatin resistance in bladder cancer } \\
\text { cells via up regulating SLC7A11. }\end{array}$ \\
\hline Bu [35] & 2014 & MiR-101 & China & Cisplatin & $\begin{array}{l}\text { MiR-101 regulates cisplatin sensitivity in bladder tumor cell lines via } \\
\text { targeting the COX-2. }\end{array}$ \\
\hline $\begin{array}{l}\text { Vinall } \\
{[36]}\end{array}$ & 2012 & MiR-34a & USA & Cisplatin & $\begin{array}{l}\text { MiR-34a sensitized tumor cells to cisplatin by targeting SIRT-1 and } \\
\text { CDK6. }\end{array}$ \\
\hline Li [37] & 2014 & MiR-34a & China & Cisplatin & MiR-34a targets CD44 after cisplatin therapy. \\
\hline Liu [38] & 2018 & MiR-34a & China & Epirubicin & $\begin{array}{l}\text { MiR-34a significantly reduced Epirubicin chemo resistance in bladder } \\
\text { tumor cells through targeting TCF1 and LEF1. }\end{array}$ \\
\hline $\begin{array}{l}\text { Zhang } \\
\text { [39] }\end{array}$ & 2017 & MiR-34a & China & Cisplatin, Gemcitabine & $\begin{array}{l}\text { MiR34a regulation of GOLPH3 is active in bladder CSCs resistant to } \\
\text { gemcitabine and cisplatin. }\end{array}$ \\
\hline $\begin{array}{l}\text { Tan } \\
{[40]}\end{array}$ & 2019 & $\begin{array}{l}\text { MiR-34b- } \\
3 p\end{array}$ & China & $\begin{array}{l}\text { Paclitaxel, Adriamycin, Epirubicin, } \\
\text { Cisplatin, Pirarubicin }\end{array}$ & $\begin{array}{l}\text { MiR-34b-3p attenuated chemo resistance in bladder cancer through } \\
\text { suppressing CCND2 and P2RY1. }\end{array}$ \\
\hline $\begin{array}{l}\text { Luan } \\
{[41]}\end{array}$ & 2018 & MiR-98 & China & Cisplatin, Doxorubicin & MiR-98 promotes chemo-resistance through targeting LASS2. \\
\hline Li [42] & 2019 & $\begin{array}{l}\text { MiR-101- } \\
3 p\end{array}$ & China & Cisplatin & $\begin{array}{l}\text { MiR-101-3p decreased cisplatin-resistance in bladder urothelial carcin } \\
\text { oma through repressing EZH2 and MRP1. }\end{array}$ \\
\hline $\begin{array}{l}\text { Cao } \\
{[43]}\end{array}$ & 2018 & $\begin{array}{l}\text { MiR-129- } \\
5 p\end{array}$ & China & Gemcitabine & $\begin{array}{l}\text { MiR-129-5p inhibits resistance to gemcitabine in bladder cancer cells } \\
\text { and promotes their apoptosis via targeting WNT5a. }\end{array}$ \\
\hline
\end{tabular}


Table 1 all of the ncRNAs associated with chemotherapeutic resistance in BCa (Continued)

\begin{tabular}{|c|c|c|c|c|c|}
\hline Study & Year & Gene & Country & Drug & Results \\
\hline LV [44] & 2015 & $\begin{array}{l}\text { MiR- } \\
\text { 193a-3p }\end{array}$ & China & $\begin{array}{l}\text { Pirarubicin, Paclitaxel, } \\
\text { Adriamycin, } \\
\text { Epirubicin Hydrochloride, and } \\
\text { Cisplatin }\end{array}$ & $\begin{array}{l}\text { MiR-193a-3p mediated HOXC9 down regulation which resulted in } \\
\text { poorer sensitivity to chemotherapeutic drugs. }\end{array}$ \\
\hline $\begin{array}{l}\text { Deng } \\
{[45]}\end{array}$ & 2015 & $\begin{array}{l}\text { MiR- } \\
\text { 193a-3p }\end{array}$ & China & $\begin{array}{l}\text { Pirarubicin, Paclitaxel, Adriamycin, } \\
\text { Epirubicin hydrochloride, and } \\
\text { Cisplatin }\end{array}$ & $\begin{array}{l}\text { PSEN1 was directly targeted by miR-193a-3p and executed its impact on } \\
\text { the multi-chemo resistance. }\end{array}$ \\
\hline Lin [46] & 2017 & $\begin{array}{l}\text { MiR- } \\
193 b-3 p\end{array}$ & Taiwan & Cisplatin & CEBPD/miR-193b-3p axis had key roles in cisplatin response. \\
\hline $\begin{array}{l}\text { Deng } \\
{[47]}\end{array}$ & 2014 & $\begin{array}{l}\text { MiR- } \\
\text { 193a-3p }\end{array}$ & China & $\begin{array}{l}\text { Paclitaxel, Adriamycin, Epirubicin } \\
\text { Hydrochloride, and Cisplatin }\end{array}$ & $\begin{array}{l}\text { MiR-193a-3p induced multi-drug resistance in bladder cancer cells } \\
\text { through down regulating LOXL } 4 \text {. }\end{array}$ \\
\hline LV [48] & 2014 & $\begin{array}{l}\text { MiR- } \\
\text { 193a-3p }\end{array}$ & China & $\begin{array}{l}\text { Pirarubicin hydrochloride, Paclitaxel, } \\
\text { Adriamycin, and Epirubicin } \\
\text { hydrochloride }\end{array}$ & $\begin{array}{l}\text { HIC2, SRSF2, and PLAU achieve their role in relaying miR-193a-3p's } \\
\text { effect on chemo resistance in bladder cancer through regulation of } \\
\text { Myc/Max, NF-jB, DNA damage response, and NOTCH pathway. }\end{array}$ \\
\hline $\begin{array}{l}\text { Shindo } \\
{[49]}\end{array}$ & 2018 & $\begin{array}{l}\text { MiR- } \\
200 \mathrm{~b}\end{array}$ & Japan & Cisplatin & $\begin{array}{l}\text { TNFSF10, ICAM1, and IGFBP3 were induced in the resistant cells as a } \\
\text { result of miR-200b + cisplatin treatment. }\end{array}$ \\
\hline $\begin{array}{l}\text { Zhang } \\
{[50]}\end{array}$ & 2015 & MiR-203 & China & Cisplatin & $\begin{array}{l}\text { The miR-203 up regulation increased the cytotoxic effects of cisplatin } \\
\text { and decreased tumor cell viability through suppressing Survivin and } \\
\text { BCL-W. }\end{array}$ \\
\hline Liu [51] & 2018 & MiR-214 & China & Cisplatin & $\begin{array}{l}\text { MiR-214 decreased chemo resistance in bladder cancer tissues and cell } \\
\text { lines by suppressing NTN1. }\end{array}$ \\
\hline $\mathrm{Li}[52]$ & 2017 & MiR-218 & China & Cisplatin & $\begin{array}{l}\text { MiR-218 up regulation reduced cisplatin resistance through GLUT1 } \\
\text { targeting. }\end{array}$ \\
\hline $\begin{array}{l}\text { Zeng } \\
{[53]}\end{array}$ & 2016 & MiR-222 & China & Cisplatin & $\begin{array}{l}\text { MiR-222 up regulation decreased cisplatin-induced apoptosis in bladder } \\
\text { tumor cells through modulation of PPP2R2A/Akt/mTOR pathway. }\end{array}$ \\
\hline
\end{tabular}

related to inducing drug resistance including $M D R 1$, $M R P 2$, and LRP. Therefore, FOXD2-AS1 regulated gemcitabine-resistance in $\mathrm{BCa}$ cells. FOXD2-AS1 indirectly targets the $\mathrm{ABCC} 3$ through miR-143 sponging [23]. Insulin-like growth factor-1 receptor (IGF$1 \mathrm{R})$ has pivotal role in cell survival, differentiation, proliferation, and apoptosis inhibition [71]. IGF-1R activates the PI3K/AKT signaling which is critical for cell survival [72, 73]. MiR-143 up regulation suppresses tumor cells proliferation and migration, and triggers apoptosis. It also increases the oxaliplatin sensitivity of tumor cells through targeting IGF-1R [74]. It has been reported that there was significant decreased levels of miR-143 expression in bladder tumor cell lines and tissue samples compared with normal margins. There was an inverse association between miR-143 and IGF-1R mRNA expression levels which showed that the miR-143 exerts its tumorsuppressive role through IGF-1R regulation. MiR-143 overexpression significantly inhibited the p-ERK and p-AKT levels. It also attenuated the gemcitabine resistance via IGF-1R suppression [24].

LnRNAs can also be associated with drug response during tumor progression through regulation of different signaling pathways [75]. Studies have confirmed the association between up regulation of IncRNA urothelial carcinoma associated 1 (UCA1) in bladder tumor tissue with cell growth, invasion, and migration [76]. UCA1 is frequently up regulated in bladder malignancies and contributed to aggressiveness of bladder tumor cells [76]. WNT signaling is an important pathway during embryogenesis and carcinogenesis [77, 78]. A significant UCA1 up regulation has been shown in bladder tumor tissues following cisplatin treatment. UCA1 overexpression was also contributed to up regulation of WNT6 and induction of WNT pathway which promotes cisplatin resistance in tumor cells [25]. The WNT6 and SRPK1 are up regulated as a result of $U C A 1$ overexpression, which leads to cisplatin resistance [25, 79]. UCA1 promotes epithelial-mesenchymal transition (EMT) and activates mTOR and ERK pathways, and increases Gefitinib resistance in EGFR-mutant lung carcinoma [80]. It has been reported that the $U C A 1$ activates $m i R$ $196 a-5 p$ via CREB which results in gemcitabine/cisplatin resistance. UCA1 up regulation had a significant association with diminished rate of apoptosis and higher cell survival. UCA1 promotes CREB phosphorylation through AKT pathways. Therefore, UCA1-dependent CREB activation was considered as a key step in miR196a-5p transcriptional regulation in bladder tumor cells [26]. TUG1 is an oncogenic lncRNA in various cancers [81-86]. Doxorubicin (Dox) is an anthracycline antibiotic which induces cell cycle arrest and apoptosis through induction of the double-strand breaks [87]. It has been reported that the TUG1 knockdown decreased Dox resistance through restraining the activity of Wnt/ 
$\beta$-catenin pathway; whereas, TUG1 up regulation was significantly associated with Dox resistance and poor prognosis [27]. CDKN2B-AS is an oncogenic lncRNA in various cancers [88-90]. Gemcitabine is a deoxycytidine analogue with anticancer function, which is used as the first-line chemotherapeutic medication against bladder urothelial carcinoma. It is metabolized and activated by cytidine deaminase and deoxycytosine kinase, respectively. It disrupts the replication of DNA, causes cell cycle arrest at G1/S stage, and promotes apoptosis [91]. It has been reported that there was up regulation of $C D K N 2 B$ $A S$ in bladder urothelial carcinoma tissues and cell line which was positively associated with advance tumor grade. $C D K N 2 B-A S$ up regulation was also correlated with Gemcitabine chemo resistance in $\mathrm{BCa}$ patients. Suppression of CDKN2B-AS attenuated the Gemcitabineresistance in $24 / \mathrm{Gem}$ cells through inactivation of WNT signaling pathway. Therefore, CDKN2B-AS induced Gemcitabine-resistance via sponging Let-7 for activating WNT signaling pathway [28]. Although, anti-neoplastic chemotherapeutic drugs like gemcitabine at first show beneficial effects in almost all patients, a noticeable ratio of patients experience recurrences following resistance. TGF $\beta 1$ is a cytokine involved in EMT and self-renewal [92]. NF90 is also a RNA binding protein with critical roles in RNA processing, localization, turnover, and transcriptional stability of HIF-1 $\alpha, I L-2$, and VEGF [93-96]. The up regulation of CSC markers such as CK14, CK5, and CD44 indicated that the BCa stemness is stimulated during chemotherapy. TGF 1 was overexpressed following Gemcitabine treatment. Moreover, aberrant expression of IncRNA-LET/NF90/miR-145 pathway was mediated by TGF $\beta 1$ which eventually increased stemness and chemo resistance. KLF4 and HMGA2 as the miR-145 targets were responsible for miR-145 suppressive effect against the stemness of $\mathrm{BCa}$ cell [29].

The DLEU1 is an IncRNA associated with tumor cell aggressiveness and migration [97-100]. It has been shown that there were higher levels of DLEU1 expressions in bladder tumor tissues compared with normal margins. DLEU1 up regulation was also associated with worse prognosis in BCa patients. Moreover, up regulation of DLEU1 enhanced tumor growth and aggressiveness and induced cisplatin resistance through HS3ST3B1 induction. DLEU1 up regulated the HS3ST3B1 via miR-99b suppression. Overexpression of HS3ST3B1 was significantly correlated with shorter survival rates in $\mathrm{BCa}$ patients. Furthermore, ectopic HS3ST3B1 expression enhanced tumor growth, invasiveness, and cisplatin resistance [30]. NEAT1 is an oncogenic lncRNA in various cancers and promotes the cell proliferation, migration, and aggressiveness through regulation of various miRNAs. Some studies have demonstrated that NEAT1 attenuates cisplatin chemo resistance [101, 102], while other studies showed the NEAT1 as inducer of cisplatin resistance $[103,104]$. It has been demonstrated that the NEAT1.1 was down regulated following cisplatin treatment in BCa cells. The p53, OCT4, and c-MYC regulated the expression level of NEAT1 through interacting with its promoter region. There were OCT4, c-MYC, and p53 up regulations in cisplatin-resistant $\mathrm{BCa}$ cells. The knockdown of NEAT1 suppressed the proliferation and migration of $\mathrm{BCa}$ cells and induced apoptosis following cisplatin treatment [31].

\section{MicroRNA-22-3p and 27a}

Neuroepithelial cell transforming 1 (NET1) is a guanine nucleotide exchange factor for RhoA and is involved in regulating extracellular signal transduction. It has been observed that the miR-22-3p enhanced resistance to chemotherapy in bladder tumor cells through suppressing NET1. NET1 was also markedly up regulated in 5637 cell line compared with $\mathrm{H}$-bc cell line. Moreover, there was an inverse association between NET1 and $m i R-22-3 p$ expression levels. NET1 was introduced as the direct target of $m i R-22-3 p$ in chemo resistance of bladder tumor cells [32]. MiR-27a down regulation in bladder tumors can be associated with reduced chemotherapeutic response [34, 105-107].

RUNX-1 is a direct target for inducing tumor chemosensitivity using miR-27a. The findings have shown a significant correlation between miR-27a overexpression and improved chemotherapeutic outcomes. The carriers of rs11671784 A allele had significantly poorer outcomes after chemotherapy compared with rs11671784 GG homozygote patients. It was also indicated that the miR$27 a$ significantly down regulated the $\mathrm{P}$-glycoprotein [108]. It has been reported that the $m i R-27 a$ up regulation was significantly associated with overexpression of CASP3 and BAX, and BCL-2 down regulation. MiR-27a decreased tumor cells' resistance to chemotherapy by increased rate of apoptosis. There was a correlation between rs11671784 G/A variation and reduced $m i R$ $27 a$ expression which results in increased RUNX-1 expression drug resistance. RUNX-1 up regulation was significantly correlated with reduced bladder tumor drug sensitivity. Therefore, miR-27a/RUNX-1 pathway has a key function in chemo-resistance in bladder malignancies [33]. Many solid tumors display resistance towards cisplatin mainly due to sequestration, reduced uptake, and increased drug efflux. Sequestration of cisplatin is accomplished by a variety of substances such as glutathione (GSH) as an efficient electron donor involved in detoxification of xenobiotics [109]. Glutathione shows antagonistic effect against cytotoxicity of radiotherapy and chemo therapeutic medication [110]. Glutamatecysteine ligase catalyzes the first step of GSH synthesis that is regulated by the availability of cystine at both 
transcription and translation levels [111]. Heterodimeric xc- cystine-glutamate transporter is an antiporter which simultaneously exports glutamate and imports cystine [112], and is consisted of SLC3A2 and SLC7A11. It has been observed that the miR-27a deregulation induced cisplatin resistance in $\mathrm{BCa}$ cells via up regulating SLC7A11, followed by increased cystine import and higher intracellular glutathione levels. The results suggested that the miR-27a/27b and SLC7A11 expression levels along with intracellular glutathione levels in $\mathrm{BCa}$ tissue could be considered as predictive factor for determining the probability of cisplatin-chemo resistance. Patients with down regulated SLC7A11 showed better response to therapy and had better prognosis [34]. $\mathrm{Cy}$ clooxygenase-2 (COX-2) is an important mediator for the synthesis of inflammatory prostaglandins and is involved in tumor invasion, angiogenesis, and drug resistance $[113,114]$. There is a negative correlation between $m i R-101$ and $C O X-2$ expressions in which $m i R$ 101 up regulation reduces cisplatin-chemo resistance through COX-2 inhibition [115]. It has been shown that there was a significant decreased expression of miR-101 in BCa cells resistant to cisplatin. Therefore, miR-101 regulates cisplatin sensitivity in bladder tumor cell lines via targeting the $\mathrm{COX}-2$ [35].

\section{MicroRNA-34a and 98}

$M i R-34 a$ is a potential tumor suppressor miRNA and its down regulation has been reported in various malignancies [116]. Dysregulated miR-34a has been associated with resistance to chemotherapeutic drugs [36, 117120]. This might be due to the modulating impact of $m i R-34 a$ on p53 signaling pathway. Ectopic expression of $m i R-34 a$ caused apoptosis, cell cycle arrest, and drug response alteration through SIRT-1,CDK6, E2F3, and $B C L-2$ targeting [121-123]. CD44 is considered as the marker of chemo-resistant bladder CSCs [124-126]. It has been reported that there was a correlation between miR-34a up regulation and cisplatin sensitivity in $\mathrm{BCa}$. Moreover, miR-34a targets CD44 after cisplatin therapy [37]. It has been reported that up regulation of $m i R-34 a$ significantly reduced Epirubicin chemo resistance in bladder tumor cells through targeting TCF1 and LEF1. Therefore, miR-34a up regulation leads to the suppression of WNT signaling pathway while increasing the rate of epirubicin -induced apoptosis [38]. Golgi phosphoprotein 3 (GOLPH3) is involved in Golgi trafficking [127]. GOLPH3 deregulation is associated with poor prognosis in $\mathrm{BCa}$ [128]. It has been reported that there was a significant reduced $m i R-34 a$ expression in gemcitabineresistant $\mathrm{BCa}$ cells. MiR-34a reduced the stemness of chemo resistant $\mathrm{BCa}$ cells and increased gemcitabine and cisplatin responses. GOLPH3 was also significantly over expressed in $\mathrm{BCa}$ cells, xenograft, and sphere cells resistant to gemcitabine and cisplatin. Moreover, the up regulation of CSC biomarkers including KLF4, SOX2, and CD44 were observed in bladder tumor cells and xenograft. Therefore, $m i R-34 a$ regulation of GOLPH3 is active in bladder CSCs resistant to gemcitabine and cisplatin [39]. Aberrant p53/Rb signaling pathway is correlated with increased tumor invasiveness and growth in muscle invasive $\mathrm{BCa}$ [129-131]. The expression levels of components of this pathway are important in predicting the clinical outcome of the chemotherapy. E2Fs as downstream effectors of $\mathrm{Rb}$, and CDK6 as regulator of $\mathrm{Rb}$ phosphorylation are directly targeted by $m i R-34 a$. MiR-34a enhances apoptosis rate through suppressing $B C L-2$ expression. CDK6 interacts with CDK4 and CCND1 to form a complex which is fundamental for $\mathrm{Rb}$ function and G1/S transition. SIRT-1 is a NADdependent deacetylase which targets FOXO, SFRP1, p53, and PGC1 [132-134]. It has been reported that the miR$34 a$ sensitized tumor cells to cisplatin by targeting SIRT1 and CDK6. The MI-TCC patients resistant toward cisplatin chemotherapy had significantly lower levels of miR-34a expression compared with sensitive patients [36]. Cyclin is critical for the regulation of cyclindependent kinase (CDK) activity. Cyclin D-CDK4/6 complex has a critical role during transition from $\mathrm{G} 1$ to $\mathrm{S}$ phase $[135,136]$. The P2RY1 is a member of G-proteincoupled receptors family which is a receptor for extracellular ADP $[137,138]$. Binding of ADP to P2RY1 mobilizes intracellular calcium through activation of phospholipase $\mathrm{C}$, which results in platelet shape change and aggregation $[139,140]$. It has been reported that the miR-34b-3p attenuated chemo resistance in $\mathrm{BCa}$ through suppressing CCND2 and P2RY1 [40].

$M i R-98$ was recognized as an important agent in regulating mitochondrial activity, which increases bladder tumor cells resistance toward mitochondrial apoptosis. It was also established that miR-98 targets LASS2 tumor suppressor. There was also an inverse association between miR-98 and LASS2 mRNA levels in bladder tumors. LASS2 functions in negative regulation of mitochondrial activity and has a putative role in mediating chemo-resistance caused by $m i R-98$. Therefore, $m i R-98$ promotes chemo-resistance through targeting LASS2, which enhances mitochondrial fusion and disrupts mitochondrial membrane potential [41].

\section{MicroRNA-101, 129-5p, and 193a-3p}

MiR-101-3p is considered as a tumor suppressor and is down regulated in different malignancies such as $\mathrm{BCa}$, colorectal cancer, and breast cancer [141-144]. EZH2 as a target of miR-101-3p is a member of the Polycombgroup family involved in transcriptional repression [145]. MRP1 is a member of ATP-binding cassette (ABC) transporters which transport different molecules across 
intra- and extra-cellular membranes. It induces chemo resistance via exporting chemotherapeutic medications before they exert their antineoplastic effects [146-148]. It has been reported that there were $m i R-101-3 p$ down regulations in bladder urothelial carcinoma tissues and cell lines resistant to cisplatin. MiR-101-3p overexpression also suppressed the MRP1 expression level. Therefore, $m i R-101-3 p$ decreased cisplatin-resistance in bladder urothelial carcinoma through repressing EZH2 and MRP1 [42]. Gemcitabine is a deoxycytidine analogue which disrupts DNA synthesis, induces replicationassociated DNA double-strand breaks, and triggers apoptosis in cancer cells. Gemcitabine is effective in improving overall survival (OS) in metastatic $\mathrm{BCa}$ patients [149].

$\mathrm{NOTCH}$ signaling pathway has a pivotal role in various cellular processes such as cell cycle, migration, metabolism, and apoptosis $[150,151]$. MiR-129-5p is involved in tumor cells drug response via modulation of NOTCH signaling receptor DLK1 [152]. WNT5a is also a member of WNT ligand family, which has critical role is regulation of cell proliferation and migration [24]. WNT5a increases the GSK-3-independent degradation of $\beta$-catenin [153-155]. Some studies have revealed that WNT5a induces resistance to chemotherapy via up regulating $\mathrm{ABCB} 1$ [156] and inducing PI3K/AKT signaling pathway [157]. It has been reported that lower levels of miR-129-5p was correlated with lower sensitivity of $\mathrm{BCa}$ cells to gemcitabine therapy; however, overexpression of miR-129-5p inhibits resistance to gemcitabine in $\mathrm{BCa}$ cells and promotes their apoptosis via targeting WNT5a [43].

Substantial epigenetic changes along with genetic variations are the origin of all cancerous features [158]. These epigenetic changes and defects have a more significant impact on tumor cells phenotype and gene expression than genetic changes. Detection of aberrant DNA methylation at promoter sequence of oncogene and tumor suppressor genes is an efficient method of early diagnosis [159-161]. MiR-193a-3p impedes tumor proliferation and decreases drug resistance through down regulation of various genes such as CCND1, ERBB4, and PTEN [162, 163]. HOXC9 belongs to highly conserved homeobox family of genes, and encodes proteins that function as homeodomain transcription factors playing a crucial role in morphogenesis in all multicellular organisms. It has been revealed that the miR-193a-3p mediated HOXC9 down regulation which resulted in poorer sensitivity of $\mathrm{BCa}$ to chemotherapeutic drugs. Oxidative stress and DNA damage response were also influenced by epigenetic suppression of HOXC9 through $m i R-193 a-3 p$ [44]. Presenilin (PSEN1) is a catalytic element of the $\gamma$-secretase complex that performs intramembrane cleavage of numerous protein substrates leading to activation of the $\mathrm{NOTCH}$ pathway [164]. Studies have shown the positive impact of PSEN1 on overexpression of ABCC1/ MRP1 via NOTCH signaling [165]. It has been reported that the PSEN1 was directly targeted by miR-193a-3p and executed its impact on the multichemo resistance. PSEN1 up regulation rendered $\mathrm{H}$ bc cells more sensitive to chemotherapy-induced cell death. However, RNA interference-mediated repression of PSEN1 gene resulted in lower rates of apoptosis and desensitizing 5637 cell line to chemotherapy-induced cell death [45]. Platinum compounds are frequently used for treatment of various malignancies by forming bifunctional DNA adducts which results in transcriptional suppression and apoptosis induction [46]. C/EBP is a family of transcription factors with pivotal roles in regulation of cellular differentiation, proliferation, and apoptosis [166-168]. CEBPD is also involved in genomic stability through transcriptional modulation of DNA damage response proteins. It was observed that CEBPD and cisplatin increased the expression levels of $m i R-193 b-3 p$. Moreover, miR-193b-3p had regulatory effect on ETS1 and CCND1. MiR-193b-3p was also important for CDDP-triggered cell cycle arrest, cell cytotoxicity, and inhibition of cellular migration. CEBPD/miR-193b-3p axis had key roles in cisplatin response of urothelial carcinoma cells in which CEBPD up regulates the miR-193b-3p and improved cisplatin cytotoxicity in urothelial carcinoma. This process was associated with ETS1 and CCND1 down regulations, cell migration inhibition, cell cycle arrest, and cisplatin-triggered cytotoxicity in NTUB1 cell line [46]. The oncogenic function of miR-193a$3 p$ is due to its suppressive effects on various genes such as KRAS and c-KIT [169, 170]. Lysyl oxidase homolog 4 (LOXL4) is a member of the lysyl oxidase family which is necessary for the biogenesis of connective tissue by formation of crosslinks between collagens and elastin fibers. It has been indicated that the miR-193a-3p induced multi-drug resistance in $\mathrm{BCa}$ cells through down regulating LOXL4, and thus initiating oxidative stress pathway [47]. Hypermethylation of the promoter and enhancer regions are associated with epigenetically silenced status of ncRNAs and protein-coding genes. The PLAU encodes the urokinase-type plasminogen-activator protein, a serine protease which has key functions in degradation of extracellular matrix during tumor progression and metastasis. The HIC2 is a transcription factor involved in systemic lupus erythematosus [171] and digeorge syndrome [172]. SRSF2 belongs to the serine/arginine-rich family of pre-mRNA 
splicing factors [173]. HIC2 interacts with CCNT1 to positively regulate MYC/Max pathway [174, 175]. It has been reported that the HIC2, SRSF2, and PLAU achieve their role in relaying miR-193a-3p's effect on chemo resistance in $\mathrm{BCa}$ through regulation of $\mathrm{Myc} /$ Max, NF-jB, DNA damage response, and $\mathrm{NOTCH}$ pathway [48].

\section{MicroRNA-200b, 203, 214, 218, and 222}

Members of $m i R-200$ family are potent inhibitors of EMT through inhibiting the expression of ZEB1 and ZEB2 [176, 177]. IGFBP3 is an important mediator of insulin growth factor (IGF) signaling pathway. IGF1 shows higher affinity for interaction with IGFBP3 than its specific receptor (IGF1R), thereby IGF1's binding to IGFBP3 interrupts accurate interaction between IGF1 and IGF1R, dampening the anti-apoptotic functions of IGF1 [178]. TNFSF10 belongs to the TNF superfamily and promotes the apoptosis of tumor cells through activation of death receptors [179]. It has been reported that there was a correlation between epigenetic silencing of $m i R-200 b$ and cisplatin resistance in BCa. Microarray analysis showed that genes associated with CDDP sensitivity or cytotoxicity, such as TNFSF10, ICAM1, and IGFBP3 were induced in the resistant cells as a result of $\mathrm{miR}-200 \mathrm{~b} /$ cisplatin treatment [49].

Although, Cisplatin is the main drug in $\mathrm{BCa}$ combination chemotherapy regimens including GC (gemcitabine and cisplatin) and MVAC (methotrexate, vinblastine, doxorubicin, and cisplatin), almost half of the MIBC patients do not respond to the cisplatin-based treatment [180]. BCL-w exerts its anti-apoptotic effects through regulation of the intrinsic apoptotic pathway [181]. Anti-apoptotic activity of survivin is accomplished through blocking the caspases in a complex with XIAP [182]. It has been reported that there was a correlation between miR-203 down regulation and poor prognosis in BCa patients who were under cisplatin-based chemotherapy. MiR-203 up regulation also increased the cytotoxic effects of cisplatin and decreased tumor cell viability through suppressing Survivin and BCL-w. Patients with non-progressive form of $\mathrm{BCa}$ had notably higher levels of miR-203 compared with cases with progressive form [50].

$M i R-214$ functions as a tumor suppressor agent and is deregulated in various cancers [183-186]. Down regulation of miR-214 occurs in $\mathrm{BCa}$ which shows marked correlation with higher tumor grade/stage and lymph nodes involvement [187]. MiR-214 down regulates the P53 and PDRG1 in $\mathrm{BCa}$ [187]. It has been revealed that there was a significant decreased level of $m i R-214$ expression in BCa tissues and cell lines. The miR-214 attenuated chemo resistance through apoptosis induction. It was able to down regulate the PARP and CASP-3 levels. It also inhibited AKT phosphorylation.
AKT signaling pathways regulates chemotherapy-induced apoptosis via BCL-2 up regulation. Therefore, the impact of $m i R-214$ on drug resistance is mediated through its modulatory function in AKT/BCL-2 axis. The miR-214 decreased chemo resistance in $\mathrm{BCa}$ tissues and cell lines by suppressing NTN1 [51].

Cisplatin mainly functions through induction of oxidative stress [188]. Nevertheless, a large fraction of tumors develop cisplatin chemo resistance through reducing drug uptake, increasing drug efflux, inactivating ROS, and increasing the intracellular level of GSH [189]. GLUT1 is a uniporter facilitating the transport of glucose across the plasma membrane and mediates glycolytic flux in cells [190]. It has been reported that the miR-218 up regulation markedly decreased glucose uptake through GLUT1 targeting. Over expression of $m i R-218$ was also beneficial in attenuating cisplatin resistance in $\mathrm{BCa}$ cells [52].

Aberrant expression of miR-222 enhances tumor cell proliferation and metastasis by inhibiting the PPP2R2A, TIMP3, and p27 [191-193]. MiR-222 expression has been linked to the tumor drug response [194]. PP2A is regarded as a master regulator of cell cycle and is also involved in the regulation of protein synthesis, apoptosis, and stress responses [191, 195-197]. It has been reported that the miR-222 up regulation increased cell proliferation and decreased cisplatininduced apoptosis in bladder tumor cells through modulation of PPP2R2A/AKT/mTOR pathway. Tumor cells with high levels of $m i R-222$ had activated AKT/mTOR axis. The mTOR or AKT suppression were also beneficial in inhibiting tumor cells' proliferation and restoring cisplatin sensitivity due to miR-222 up regulation [53].

\section{Conclusions}

Regarding the importance of ncRNAs in regulation of drug response in tumor cells, in present review we have summarized all of the reported ncRNAs which are associated with chemotherapeutic resistance in $\mathrm{BCa}$. It was observed that the IncRNAs were the most reported ncRNAs associated with drug response of $\mathrm{BCa}$. This review paves the way of introducing a prognostic panel of ncRNAs for the BCa patients to improve the selection of an efficient chemotherapeutic strategy based on ncRNA profile of $\mathrm{BCa}$ patients.

\footnotetext{
Abbreviations

NMIBC: Non-Muscle-Invasive Bladder Cancer; BCa: Bladder cancer; ncRNAs: Non-coding RNAs; MIBC: Muscle-invasive bladder cancer; BCG: Bacille Calmette-Guérin; IncRNA: Long non-coding RNAs; miRNA: Micro RNAs; circRNA: Circular RNAs; SIRT1: Sirtuin-1; HMGA1: High-mobility group A1; IGF-1R: Insulin-like growth factor-1 receptor; UCA1: Urothelial carcinoma associated 1; EMT: Epithelial-mesenchymal transition; GHET1: Gastric carcinoma proliferation-enhancing transcript 1; Dox: Doxorubicin; NET1: neuroepithelial cell transforming 1; GSH: Glutathione; COX2: Cyclooxygenase-2; GOLPH3: Golgi phosphoprotein 3; ABC: ATP-binding cassette; OS: Overall survival; PSEN1: Presenilin; C/EBP: CCAAT/enhancer binding protein; IGF: Insulin growth factor
} 


\section{Acknowledgements}

Not applicable.

\section{Authors' contributions}

ASZ, HRR, MMojarrad were involved in search strategy and drafting MMoghbeli supervised the project and revised and edited the manuscript. All authors read and approved the final manuscript.

\section{Funding}

Not applicable.

\section{Availability of data and materials}

The datasets used and/or analyzed during the current study are available from the corresponding author on reasonable request.

\section{Ethics approval and consent to participate}

Not applicable.

\section{Consent for publication}

Not applicable.

\section{Competing interests}

The authors declare that they have no competing interests.

\section{Author details}

'Student Research Committee, Faculty of Medicine, Mashhad University of Medical Sciences, Mashhad, Iran. ${ }^{2}$ Department of Medical Genetics and Molecular Medicine, School of Medicine, Mashhad University of Medical Sciences, Mashhad, Iran.

Received: 19 June 2020 Accepted: 5 November 2020

Published online: 12 November 2020

\section{References}

1. Ploeg M, Aben KK, Kiemeney LA. The present and future burden of urinary bladder cancer in the world. World J Urol. 2009;27(3):289-93.

2. Siegel RL, Miller KD, Jemal A. Cancer statistics, 2017. CA Cancer J Clin. 2017; 67(1):7-30

3. Burger $\mathrm{M}$, et al. Epidemiology and risk factors of urothelial bladder cancer. Eur Urol. 2013:63(2):234-41.

4. Amling CL. Diagnosis and management of superficial bladder cancer. Curr Probl Cancer. 2001:25(4):IN1-278.

5. Sharma S, Ksheersagar P, Sharma P. Diagnosis and treatment of bladder cancer. Am Fam Physician. 2009;80(7):717-23.

6. Stenzl A, et al. Treatment of muscle-invasive and metastatic bladder cancer: update of the EAU guidelines. Eur Urol. 2011:59(6):1009-18.

7. Martinez Rodriguez RH, Buisan Rueda O, Ibarz L. Bladder cancer: present and future. Med Clin (Barc). 2017;149(10):449-55.

8. Kim HL, Steinberg GD. The current status of bladder preservation in the treatment of muscle invasive bladder cancer. J Urol. 2000;164(3 Pt 1): 627-32.

9. von der Maase H, Sengelov L, Roberts JT, Ricci S, Dogliotti L, Oliver T, Moore MJ, Zimmermann A, Arning M. Long-term survival results of a randomized trial comparing gemcitabine plus cisplatin, with methotrexate, vinblastine, doxorubicin, plus cisplatin in patients with bladder cancer. J Clin Oncol. 2005;23(21):4602-8.

10. Tanji $\mathrm{N}$, et al. Long-term results of combined chemotherapy with gemcitabine and cisplatin for metastatic urothelial carcinomas. Int J Clin Oncol. 2010;15(4):369-75.

11. Hoeijmakers JH. DNA damage, aging, and cancer. N Engl J Med. 2009; 361(15):1475-85

12. Lawrence MS, et al. Mutational heterogeneity in cancer and the search for new cancer-associated genes. Nature. 2013;499(7457):214-8.

13. Mojarrad M, Moghbeli M. Genetic and molecular biology of bladder cancer among Iranian patients. Mol Genet Genomic Med. 2020;8:e1233.

14. Ding $B$, et al. Non-coding RNA in drug resistance of hepatocellula carcinoma. Biosci Rep. 2018;38(5):BSR20180915

15. Ma J, Dong C, Ji C. MicroRNA and drug resistance. Cancer Gene Ther. 2010; 17(8):523-31.
16. Rahmani Z, Mojarrad M, Moghbeli M. Long non-coding RNAs as the critical factors during tumor progressions among Iranian population: an overview. Cell Biosci. 2020;10:6.

17. Chen J, Li Y, Li Z, Cao L. LnCRNA MST1P2/miR-133b axis affects the chemoresistance of bladder cancer to cisplatin-based therapy via Sirt1/p53 signaling. J Biochem Mol Toxicol. 2020;34(4):e22452.

18. Chen X, Liu M, Meng F, Sun B, Jin X, Jia C. The long noncoding RNA HIF1AAS2 facilitates cisplatin resistance in bladder cancer. J Cell Biochem. 2019: 120(1):243-52.

19. Wu J, Li W, Ning J, Yu W, Rao T, Cheng F. Long noncoding RNA UCA1 targets miR-582-5p and contributes to the progression and drug resistance of bladder cancer cells through ATG7-mediated autophagy inhibition. Onco Targets Ther. 2019;12:495.

20. Zhang H, Guo Y, Song Y, Shang C. Long noncoding RNA GAS5 inhibits malignant proliferation and chemotherapy resistance to doxorubicin in bladder transitional cell carcinoma. Cancer Chemother Pharmacol. 2017; 79(1):49-55.

21. Liu P, Li X, Cui Y, Chen J, Li C, Li Q, Li H, Zhang X, Zu X. LnCRNA-MALAT1 mediates cisplatin resistance via miR-101-3p/NEGF-C pathway in bladder cancer. Acta Biochim Biophys Sin. 2019;51(11):1148-57.

22. Li B, Xie D, Zhang H. Long non-coding RNA GHET1 contributes to chemotherapeutic resistance to Gemcitabine in bladder cancer. Cancer Chemother Pharmacol. 2019;84(1):187-94.

23. An Q, Zhou L, Xu N. Long noncoding RNA FOXD2-AS1 accelerates the gemcitabine-resistance of bladder cancer by sponging miR-143. Biomed Pharmacother. 2018;103:415-20.

24. Wang H, Li Q, Niu X, Wang G, Zheng S, Fu G, Wang Z. miR-143 inhibits bladder cancer cell proliferation and enhances their sensitivity to gemcitabine by repressing IGF-1R signaling. Oncol Lett. 2017;13(1):435-40.

25. Fan Y, Shen B, Tan M, Mu X, Qin Y, Zhang F, Liu Y. Long non-coding RNA UCA 1 increases chemoresistance of bladder cancer cells by regulating Wnt signaling. FEBS J. 2014;281(7):1750-8.

26. Pan J, Li XU, Wu W, Xue M, Hou H, Zhai W, Chen W. Long non-coding RNA UCA1 promotes cisplatin/gemcitabine resistance through CREB modulating miR-196a-5p in bladder cancer cells. Cancer Lett. 2016;382(1):64-76.

27. Xie D, Zhang H, Hu X, Shang C. Knockdown of long non-coding RNA Taurine Up-Regulated 1 inhibited doxorubicin resistance of bladder urothelial carcinoma via Wnt/ß-catenin pathway. Oncotarget. 2017;8(51): 88689.

28. Xie D, Zhang $H$, Shang $C$. Long non-coding RNA CDKN2B antisense RNA 1 gene inhibits Gemcitabine sensitivity in bladder urothelial carcinoma. J Cancer. 2018;9(12):2160

29. Zhuang J, Shen L, Yang L, Huang X, Lu Q, Cui Y, Zheng X, Zhao X, Zhang D, Huang $\mathrm{R}$, Guo $\mathrm{H}$. TGFß1 promotes gemcitabine resistance through regulating the LnCRNA-LET/NF90/miR-145 signaling axis in bladder cancer. Theranostics. 2017;7(12):3053.

30. Li Y, Shi B, Dong F, Zhu X, Liu B, Liu Y. Long non-coding RNA DLEU1 promotes cell proliferation, invasion and confers cisplatin resistance in bladder cancer by regulating the miR-99b/HS3ST3B1 axis. Front Genet. 2019; 10:280

31. Zhao W, Li W, Jin X, Niu T, Cao Y, Zhou P, Zheng M. Silencing long noncoding RNA NEAT1 enhances the suppression of cell growth, invasion, and apoptosis of bladder cancer cells under cisplatin chemotherapy. Int J Clin Exp Pathol. 2019;12(2):549.

32. Xiao J, Niu S, Zhu J, Lv L, Deng H, Pan D, Shen D, Xu C, Shen Z, Tao T. miR22-3p enhances multi-chemoresistance by targeting NET1 in bladder cancer cells. Oncol Rep. 2018:39(6):2731-40.

33. Deng Y, Bai H, Hu H. rs 11671784 G/A variation in miR-27a decreases chemosensitivity of bladder cancer by decreasing miR-27a and increasing the target RUNX-1 expression. Biochem Biophys Res Commun. 2015;458(2):3217.

34. Drayton RM, Dudziec E, Peter S, Bertz S, Hartmann A, Bryant HE, Catto JW. Reduced expression of miRNA-27a modulates cisplatin resistance in bladder cancer by targeting the cystine/glutamate exchanger SLC7A11. Clin Cancer Res. 2014;20(7):1990-2000.

35. Bu Q, Fang Y, Cao Y, Chen Q, Liu Y. Enforced expression of miR-101 enhances cisplatin sensitivity in human bladder cancer cells by modulating the cyclooxygenase-2 pathway. Mol Med Rep. 2014:10(4):2203-9.

36. Vinall RL, Ripoll AZ, Wang S, Pan CX, deVere White RW. MiR-34a chemosensitizes bladder cancer cells to cisplatin treatment regardless of p53-Rb pathway status. Int J Cancer. 2012;130(11):2526-38. 
37. Li H, Yu G, Shi R, Lang B, Chen X, Xia D, Xiao H, Guo X, Guan W, Ye Z, Xiao W. Cisplatin-induced epigenetic activation of miR-34a sensitizes bladder cancer cells to chemotherapy. Mol Cancer. 2014;13(1):1-1.

38. Liu X, Liu X, Wu Y, Fang Z, Wu Q, Wu C, Hao Y, Yang X, Zhao J, Li J, Wang Q. MicroRNA-34a attenuates metastasis and chemoresistance of bladder cancer cells by targeting the TCF1/LEF1 axis. Cell Physiol Biochem. 2018; 48(1):87-98

39. Zhang Q, Zhuang J, Deng Y, Yang L, Cao W, Chen W, Lin T, Lv X, Yu H, Xue Y, Guo H. miR34a/GOLPH3 axis abrogates urothelial bladder cancer chemoresistance via reduced cancer stemness. Theranostics. 2017;7(19): 4777.

40. Tan Y, Zhang T, Zhou L, Liu S, Liang C. MiR-34b-3p represses the multidrugchemoresistance of bladder cancer cells by regulating the CCND2 and P2RY1 genes. Med Sci Monit. 2019;25:1323.

41. Luan T, Fu S, Huang L, Zuo Y, Ding M, Li N, Chen J, Wang H, Wang J. MicroRNA-98 promotes drug resistance and regulates mitochondrial dynamics by targeting LASS2 in bladder cancer cells. Exp Cell Res. 2018; 373(1-2):188-97.

42. Li B, Xie D, Zhang H. MicroRNA-101-3p advances cisplatin sensitivity in bladder urothelial carcinoma through targeted silencing EZH2. J Cancer. 2019;10(12):2628.

43. Cao J, Wang Q, Wu G, Li S, Wang Q. miR-129-5p inhibits gemcitabine resistance and promotes cell apoptosis of bladder cancer cells by targeting Wnt5a. Int Urol Nephrol. 2018:50(10):1811-9.

44. Lv L, Li Y, Deng H, Zhang C, Pu Y, Qian L, Xiao J, Zhao W, Liu Q, Zhang D, Wang Y. MiR-193a-3p promotes the multi-chemoresistance of bladder cancer by targeting the HOXC9 gene. Cancer Lett. 2015;357(1): 105-13.

45. Deng H, Lv L, Li Y, Zhang C, Meng F, Pu Y, Xiao J, Qian L, Zhao W, Liu Q, Zhang $D$. The miR-193a-3p regulated PSEN1 gene suppresses the multichemoresistance of bladder cancer. Biochimica et Biophysica Acta (BBA)Mol Basis Dis. 2015;1852(3):520-8.

46. Lin SR, Yeh HC, Wang WJ, Ke HL, Lin HH, Hsu WC, Chao SY, Hour TC, Wu WJ, Pu YS, Huang AM. MiR-193b mediates CEBPD-induced cisplatin sensitization through targeting ETS1 and cyclin D1 in human urothelial carcinoma cells. J Cell Biochem. 2017;118(6):1563-73.

47. Deng H, Lv L, Li Y, Zhang C, Meng F, Pu Y, Xiao J, Qian L, Zhao W, Liu Q, Zhang D. miR-193a-3p regulates the multi-drug resistance of bladder cancer by targeting the LOXL4 gene and the oxidative stress pathway. Mol Cancer. 2014;13(1):234

48. Lv L, Deng H, Li Y, Zhang C, Liu X, Liu Q, Zhang D, Wang L, Pu Y, Zhang H, He Y. The DNA methylation-regulated miR-193a-3p dictates the multichemoresistance of bladder cancer via repression of SRSF2/PLAU/HIC2 expression. Cell Death Dis. 2014;5(9):e1402-2.

49. Shindo T, Niinuma T, Nishiyama N, Shinkai N, Kitajima H, Kai M, Maruyama R, Tokino T, Masumori N, Suzuki H. Epigenetic silencing of miR-200b is associated with cisplatin resistance in bladder cancer. Oncotarget. 2018; 9(36):24457.

50. Zhang X, Zhang Y, Liu X, Fang A, Li P, Li Z, Liu T, Yang Y, Du L, Wang C. MicroRNA-203 is a prognostic indicator in bladder cancer and enhances chemosensitivity to cisplatin via apoptosis by targeting Bcl-w and survivin PloS One. 2015;10(11):e0143441.

51. Liu J, Bi J, Li Z, Li Z, Liu X, Kong C. miR-214 reduces cisplatin resistance by targeting netrin-1 in bladder cancer cells. Int J Mol Med. 2018;41(3):1765-73.

52. Li P, Yang $X$, Cheng $Y$, Zhang $X$, Yang $C$, Deng $X$, Li P, Tao J, Yang H, Wei J, Tang J. MicroRNA-218 increases the sensitivity of bladder cancer to cisplatin by targeting Glut1. Cell Physiol Biochem. 2017;41(3):921-32.

53. Zeng LP, Hu ZM, Li K, Xia K. miR-222 attenuates cisplatin-induced cell death by targeting the PPP 2R2A/Akt/mTOR Axis in bladder cancer cells. J Cell Mol Med. 2016;20(3):559-67.

54. Moran VA, Perera RJ, Khalil AM. Emerging functional and mechanistic paradigms of mammalian long non-coding RNAs. Nucleic Acids Res. 2012; 40(14):6391-400.

55. Anastasiadou E, Jacob LS, Slack FJJNRC. Non-coding RNA networks in cancer. Nat Rev Cancer. 2018;18(1):5.

56. Dong P, Xiong Y, Yue J, Hanley SJ, Kobayashi N, Todo Y, Watari H. Long non-coding RNA NEAT1: a novel target for diagnosis and therapy in human tumors. Front Genet. 2018;9:471.

57. Malek E, Jagannathan S, Driscoll JJJO. Correlation of long non-coding RNA expression with metastasis, drug resistance and clinical outcome in cancer. Oncotarget. 2014;5(18):8027.
58. Massari F, Santoni M, Ciccarese C, Brunelli M, Conti A, Santini D, Montironi R, Cascinu S, Tortora G. Emerging concepts on drug resistance in bladder cancer: Implications for future strategies. Crit Rev Oncol Hematol. 2015;96(1):81-90.

59. Yafi FA, North S, Kassouf W. First-and second-line therapy for metastatic urothelial carcinoma of the bladder. Curr Oncol. 2011;18(1):e25.

60. Revollo JR, Grimm AA, Imai SI. The NAD biosynthesis pathway mediated by nicotinamide phosphoribosyltransferase regulates Sir2 activity in mammalian cells. J Biol Chem. 2004;279(49):50754-63.

61. Zhang Y, Huang W, Ran Y, Xiong Y, Zhong Z, Fan X, Wang Z, Ye Q. miR582-5p inhibits proliferation of hepatocellular carcinoma by targeting CDK1 and AKT3. Tumor Biol. 2015;36(11):8309-16.

62. Zhang $X$, Zhang Y, Yang J, Li S, Chen J. Upregulation of miR-582-5p inhibits cell proliferation, cell cycle progression and invasion by targeting Rab27a in human colorectal carcinoma. Cancer Gene Ther. 2015;22(10):475-80.

63. Wang WW, Chen B, Lei CB, Liu GX, Wang YG, Yi C, Wang YY, Zhang SY. miR582-5p inhibits invasion and migration of salivary adenoid cystic carcinoma cells by targeting FOXC1. Jpn J Clin Oncol. 2017;47(8):690-8.

64. Geng J, Klionsky DJ. The Atg8 and Atg12 ubiquitin-like conjugation systems in macroautophagy. EMBO reports. 2008;9(9):859-64.

65. Jia L, Yang A. Noncoding RNAs in therapeutic resistance of cancer. Adv Exp Med Biol. 2016;927:265-95.

66. Fang Z, Chen W, Yuan Z, Liu X, Jiang H. LncRNA-MALAT1 contributes to the cisplatin-resistance of lung cancer by upregulating MRP1 and MDR1 via STAT3 activation. Biomed Pharmacother. 2018;101:536-42.

67. Zhang $X, B o P$, Liu L, Zhang $X$, Li J. Overexpression of long non-coding RNA GHET1 promotes the development of multidrug resistance in gastric cancer cells. Biomed Pharmacother. 2017;92:580-5.

68. Niedersuess-Beke D, Puntus T, Kunit T, Gruenberger B, Lamche M, Loidl W, Böhm R, Kraischits N, Kudlacek S, Schramek P, Meran JG. Neoadjuvant chemotherapy with gemcitabine plus cisplatin in patients with locally advanced bladder cancer. Oncology. 2017;93(1):36-42.

69. Ostwal V, Pinninti R, Ramaswamy A, Shetty N, Goel M, Patkar S, Mirani J, Nashikkar C, Banavali S. Treatment of advanced Gall bladder cancer in the real world_can continuation chemotherapy improve outcomes?. J Gastrointest Oncol. 2017;8(2):368.

70. Su F, He W, Chen C, Liu M, Liu H, Xue F, Bi J, Xu D, Zhao Y, Huang J, Lin T. The long non-coding RNA FOXD2-AS1 promotes bladder cancer progression and recurrence through a positive feedback loop with Akt and E2F1. Cell Death Dis. 2018;9(2):1-17.

71. Rubin R, Baserga R. Insulin-like growth factor I receptor. Its role in cell proliferation, apoptosis and tumorigenicity. Lab Invest. 1995;73(3):311-31.

72. Hanahan D, Weinberg RA. The hallmarks of cancer. cell. 2000;100(1):57-70

73. Baserga RJTib. Controlling IGF-receptor function: a possible strategy for tumor therapy. Trends Biotechnol. 1996;14(5):150-2.

74. Qian X, Yu J, Yin Y, He J, Wang L, Li Q, Zhang LQ, Li CY, Shi ZM, Xu Q, Li W. MicroRNA-143 inhibits tumor growth and angiogenesis and sensitizes chemosensitivity to oxaliplatin in colorectal cancers. Cell Cycle. 2013;12(9): 1385-94.

75. Zheng HC. The molecular mechanisms of chemoresistance in cancers. Oncotarget. 2017;8(35):59950-64.

76. Wang $\mathrm{F}$, et al. UCA1, a non-protein-coding RNA up-regulated in bladder carcinoma and embryo, influencing cell growth and promoting invasion. FEBS Lett. 2008:582(13):1919-27.

77. Abbaszadegan MR, et al. WNT and NOTCH signaling pathways as activators for epidermal growth factor receptor in esophageal squamous cell carcinoma. Cell Mol Biol Lett. 2018;23:42.

78. Moghbeli M, et al. Correlation of Wnt and NOTCH pathways in esophageal squamous cell carcinoma. J Cell Commun Signal. 2016;10(2):129-35.

79. Wang F, Zhou J, Xie X, Hu J, Chen L, Hu Q, Guo H, Yu C. Involvement of SRPK1 in cisplatin resistance related to long non-coding RNA UCA1 in human ovarian cancer cells. Neoplasm. 2015;62(3):432-8.

80. Cheng N, et al. Long non-coding RNA UCA1 induces non-T790M acquired resistance to EGFR-TKls by activating the AKT/mTOR pathway in EGFRmutant non-small cell lung cancer. Oncotarget. 2015;6(27):23582.

81. Ren $K$, Li Z, Li Y, Zhang W, Han X. Long noncoding RNA taurine-upregulated gene 1 promotes cell proliferation and invasion in gastric cancer via negatively modulating miRNA-145-5p. Oncol Res Featuring Preclinical Clin Cancer Ther. 2017:25(5):789-98.

82. Zhai HY, Sui MH, Yu X, Qu Z, Hu JC, Sun HQ, Zheng HT, Zhou K, Jiang LX. Overexpression of long non-coding RNA TUG1 promotes colon cancer progression. Med Sci Monit. 2016;22:3281. 
83. Wang $L$, et al. Long non-coding RNA TUG1 promotes colorectal cancer metastasis via EMT pathway. Oncotarget. 2016;7(32):51713.

84. Qin CF, Zhao FL. Long non-coding RNA TUG1 can promote proliferation and migration of pancreatic cancer via EMT pathway. Eur Rev Med Pharmacol Sci.2017;21(10):2377-84.

85. Iliev R, Kleinova R, Juracek J, Dolezel J, Ozanova Z, Fedorko M, Pacik D, Svoboda M, Stanik M, Slaby O. Overexpression of long non-coding RNA TUG1 predicts poor prognosis and promotes cancer cell proliferation and migration in high-grade muscle-invasive bladder cancer. Tumor Biol. 2016; 37(10):13385-90.

86. Liu J, et al. Prognostic role of IncRNA TUG1 for cancer outcome: evidence from 840 cancer patients. Oncotarget. 2017;8(30):50051.

87. Hanušová V, Boušová I, Skálová L. Possibilities to increase the effectiveness of doxorubicin in cancer cells killing. Drug Metab Rev. 2011;43(4):540-57.

88. Huang MD, Chen WM, Qi FZ, Xia R, Sun M, Xu TP, Yin L, Zhang EB, De W, Shu YQ. Long non-coding RNA ANRIL is upregulated in hepatocellular carcinoma and regulates cell proliferation by epigenetic silencing of KLF2. J Hematol Oncol. 2015;8(1):57-7.

89. Zou ZW, Ma C, Medoro L, Chen L, Wang B, Gupta R, Liu T, Yang XZ, Chen $\Pi$, Wang RZ, Zhang WJ. LncRNA ANRIL is up-regulated in nasopharyngeal carcinoma and promotes the cancer progression via increasing proliferation, reprograming cell glucose metabolism and inducing side-population stemlike cancer cells. Oncotarget. 2016;7(38):61741.

90. Liu B, et al. Expression and mechanisms of long non-coding RNA genes MEG3 and ANRIL in gallbladder cancer. Tumor Biol. 2016;37(7):9875-86.

91. de Sousa Cavalcante L, Monteiro G. Gemcitabine: metabolism and molecular mechanisms of action, sensitivity and chemoresistance in pancreatic cancer. Eur J Pharmacol. 2014;741:8-16.

92. Roussos ET, et al. AACR special conference on epithelial-mesenchymal transition and cancer progression and treatment. AACR. 2010.

93. Vumbaca F, et al. Double-stranded RNA-binding protein regulates vascular endothelial growth factor mRNA stability, translation, and breast cancer angiogenesis. Mol Cell Biol. 2008;28(2):772-83.

94. Shim J, et al. Nuclear export of NF90 is required for interleukin-2 mRNA stabilization. Mol Cell. 2002;10(6):1331-44.

95. Kuwano $Y$, et al. NF90 selectively represses the translation of target mRNAs bearing an AU-rich signature motif. Nucleic Acids Res. 2010;38(1):225-38.

96. Yang $F$, et al. Repression of the long noncoding RNA-LET by histone deacetylase 3 contributes to hypoxia-mediated metastasis. Mol Cancer. 2013;49(6):1083-96

97. Liu T, et al. LnCRNA DLEU1 contributes to colorectal cancer progression via activation of KPNA3. Mol Cancer. 2018:17(1):118.

98. Zhang $\mathrm{S}$, et al. Long non-coding RNA DLEU1 exerts an oncogenic function in non-small cell lung cancer. Biomed Pharmacother. 2019;109:985-90.

99. Wang LL, et al. DLEU 1 contributes to ovarian carcinoma tumourigenesis and development by interacting with miR-490-3p and altering CDK 1 expression. J Cell Mol Med. 2017;21(11):3055-65.

100. Gao S, et al. Long noncoding RNA DLEU1 aggravates pancreatic ductal adenocarcinoma carcinogenesis via the miR-381/CXCR4 axis. J Cell Physiol. 2019;234(5):6746-57.

101. Parasramka M, et al. BAP1 dependent expression of long non-coding RNA NEAT-1 contributes to sensitivity to gemcitabine in cholangiocarcinoma. Mol Cancer. 2017;16(1):1-22.

102. Jiang $P$, et al. NEAT1 upregulates EGCG-induced CTR1 to enhance cisplatin sensitivity in lung cancer cells. Oncotarget. 2016;7(28):43337.

103. Ru Y, et al. neaT1_2-sFPQ axis mediates cisplatin resistance in liver cancer cells in vitro. Onco Taget Ther. 2018;11:5695

104. Hu Y, et al. Knockdown of the oncogene IncRNA NEAT1 restores the availability of miR-34c and improves the sensitivity to cisplatin in osteosarcoma. Biosci Rep. 2018;38(3).

105. Nordentoft I, et al. miRNAs associated with chemo-sensitivity in cell lines and in advanced bladder cancer. BMC Med Genomics. 2012;5(1):40.

106. Duan R, Pak C, Jin P. Single nucleotide polymorphism associated with mature miR-125a alters the processing of pri-miRNA. Hum Mol Genet. 2007; 16(9):1124-31

107. Iorio MV, Croce CM. MicroRNAs in cancer: small molecules with a huge impact. J Clin Oncol. 2009;27(34):5848.

108. Diestra JE, et al. Expression of multidrug resistance proteins P-glycoprotein, multidrug resistance protein 1, breast cancer resistance protein and lung resistance related protein in locally advanced bladder cancer treated with neoadjuvant chemotherapy: biological and clinical implications. J Urol. 2003;170(4):1383-7.
109. Pastore A, et al. Analysis of glutathione: implication in redox and detoxification. Clinica chimica acta. 2003;333(1):19-39.

110. Russo A, et al. Selective modulation of glutathione levels in human normal versus tumor cells and subsequent differential response to chemotherapy drugs. Cancer Res. 1986;46(6):2845-8.

111. Wu G, et al. Glutathione metabolism and its implications for health. J Nutr. 2004;134(3):489-92.

112. Sato $\mathrm{H}$, et al. Cloning and expression of a plasma membrane cystine/ glutamate exchange transporter composed of two distinct proteins. J Biol Chem. 1999;274(17):11455-8

113. Greenhough A, et al. The COX-2/PGE 2 pathway: key roles in the hallmarks of cancer and adaptation to the tumour microenvironment. Carcinog. 2009;30(3): $377-86$.

114. Hasegawa $\mathrm{K}$, et al. Overcoming paclitaxel resistance in uterine endometrial cancer using a COX-2 inhibitor. Oncol Rep. 2013;30(6):2937-44.

115. He XP, et al. Downregulation of miR-101 in gastric cancer correlates with cyclooxygenase-2 overexpression and tumor growth. FEBS J. 2012;279(22): 4201-12.

116. Lodygin $\mathrm{D}$, et al. Inactivation of miR-34a by aberrant CpG methylation in multiple types of cancer. Cell Cycle. 2008;7(16):2591-600.

117. Wiggins JF, et al. Development of a lung cancer therapeutic based on the tumor suppressor microRNA-34. Cancer Res. 2010;70(14):5923-30.

118. Ji X, Wang Z, Geamanu A, Goja A, Sarkar FH, Gupta SV. Delta-tocotrienol suppresses Notch-1 pathway by upregulating miR-34a in nonsmall cell lung cancer cells. Int J Cancer. 2012;131(11):2668-77.

119. Nakatani F, et al. miR-34a predicts survival of Ewing's sarcoma patients and directly influences cell chemo-sensitivity and malignancy. J Pathol. 2012;226(5):796-805.

120. Li Y, et al. Amplification of LAPTMAB and YWHAZ contributes to chemotherapy resistance and recurrence of breast cancer. Nat Med. 2010; 16(2):214.

121. He $L$, et al. A microRNA component of the $p 53$ tumour suppressor network. Nature. 2007:447(7148):1130-4.

122. Tarasov V, et al. Differential regulation of microRNAs by p53 revealed by massively parallel sequencing: miR-34a is a p53 target that induces apoptosis and G1-arrest. Cell cycle. 2007;6(13):1586-93.

123. Chang T-C, et al. Transactivation of miR-34a by $p 53$ broadly influences gene expression and promotes apoptosis. Mol Cell. 2007;26(5):745-52.

124. Yang YM, Chang JW. Bladder cancer initiating cells (BCICS) are among EMACD44v6+ subset: novel methods for isolating undetermined cancer stem (initiating) cells. Cancer Invest. 2008;26(7):725-33.

125. Kuncova J, et al. Expression of CD44v6 correlates with cell proliferation and cellular atypia in urothelial carcinoma cell lines 5637 and HT1197. Folia Biol (Praha). 2005;51(1):3-11.

126. Chan KS, Espinosa I, Chao M, Wong D, Ailles L, Diehn M, Gill H, Presti J, Chang HY, van de Rijn M, Shortliffe L. Identification, molecular characterization, clinical prognosis, and therapeutic targeting of human bladder tumor-initiating cells. Proc Natl Acad Sci. 2009;106(33):14016-21.

127. Scott KL, Kabbarah O, Liang MC, Ivanova E, Anagnostou V, Wu J, Dhakal $\mathrm{S}$, Wu M, Chen S, Feinberg T, Huang J. GOLPH3 modulates mTOR signalling and rapamycin sensitivity in cancer. Nature. 2009;459(7250): 1085-90.

128. Zhang $\mathrm{Q}$, et al. GOLPH3 is a potential therapeutic target and a prognostic indicatior of poor survival in bladder cancer treated by cystectomy. Oncotarget. 2015:6(31):32177.

129. Raghavan D. Molecular targeting and pharmacogenomics in the management of advanced bladder cancer. Interdiscip Intern J Am Cancer Soc. 2003;97(S8):2083-9.

130. Shariat SF, et al. p53 expression in patients with advanced urothelial cancer of the urinary bladder. BJU Int. 2010;105(4):489-95.

131. Shariat SF, et al. p53 predictive value for pT1-2 N0 disease at radical cystectomy. J Urol. 2009;182(3):907-13.

132. Castillo-Martin M, et al. Molecular pathways of urothelial development and bladder tumorigenesis. In: Urologic oncology: seminars and original investigations. Amsterdam: Elsevier; 2010.

133. Kim JE, Lou Z, Chen J. Interactions between DBC1 and SIRT1 are deregulated in breast cancer cells. Cell Cycle. 2009;8(22):3784-5.

134. Rodon J, Perez J, Kurzrock R. Combining targeted therapies: practical issues to consider at the bench and bedside. Oncologist. 2010;15(1):37.

135. Zhang F, et al. MicroRNA-2682-3p inhibits osteosarcoma cell proliferation by targeting CCND2, MMP8 and Myd88. Oncol Lett. 2018;16(3):3359-64. 
136. Hu W, et al. MiR-373-3p enhances the chemosensitivity of gemcitabine through cell cycle pathway by targeting CCND2 in pancreatic carcinoma cells. Biomed Pharmacother. 2018;105:887-98.

137. Volonté C, D'Ambrosi N. Membrane compartments and purinergic signalling: the purinome, a complex interplay among ligands, degrading enzymes, receptors and transporters. FEBS J. 2009;276(2):318-29.

138. Smyth SS, et al. G-protein-coupled receptors as signaling targets for antiplatelet therapy. Arterioscler Thromb Vasc Biol. 2009;29(4):449-57.

139. Gremmel T, et al. Synergistic inhibition of both $P 2 Y 1$ and $P 2 Y 12$ adenosine diphosphate receptors as novel approach to rapidly attenuate plateletmediated thrombosis. Arterioscler Thromb Vasc Biol. 2016;36(3):501-9.

140. Yanachkov IB, et al. New highly active antiplatelet agents with dual specificity for platelet P2Y1 and P2Y12 adenosine diphosphate receptors. Eur J Med Chem. 2016;107:204-18.

141. Li X-N, et al. Circular RNA circVAPA is up-regulated and exerts oncogenic properties by sponging miR-101 in colorectal cancer. Biomed Pharmacother 2019:112:108611

142. Li C-Y, et al. Clinical value of miR-101-3p and biological analysis of its prospective targets in breast cancer: a study based on The Cancer Genome Atlas (TCGA) and bioinformatics. Med Sci Monit. 2017;23:1857.

143. Jin $Q$, et al. MicroRNA-101-3p inhibits proliferation in retinoblastoma cells by targeting EZH2 and HDAC9. Exp Ther Med. 2018;16(3):1663-70.

144. Liu D, et al. LncRNA SPRY4-IT1 sponges miR-101-3p to promote proliferation and metastasis of bladder cancer cells through up-regulating EZH2. Cancer Lett. 2017;388:281-91.

145. Yamagishi M, Uchimaru K. Targeting EZH2 in cancer therapy. Curr Opin Oncol. 2017;29(5):375-81.

146. Lu JF, Pokharel D, Bebawy M. Bebawy, MRP1 and its role in anticancer drug resistance. Drug Metab Rev. 2015;47(4):406-19

147. Zhang Y-K, et al. Multidrug resistance proteins (MRPs) and cancer therapy. AAPS J. 2015;17(4):802-12.

148. Yan $X$, et al. Visfatin mediates doxorubicin resistance in human colorectal cancer cells via up regulation of multidrug resistance 1 (MDR1). Cancer Chemother Pharmacol. 2017:80(2):395-403.

149. Anghel $\mathrm{R}$, et al. Outcome of urinary bladder cancer after combined therapies. J Med Life. 2016:9(2):153.

150. Moghbeli M, et al. Role of Msi1 and MAML1 in regulation of Notch signaling pathway in patients with esophageal squamous cell carcinoma. J Gastrointest Cancer. 2015;46(4):365-9.

151. Moghbeli M, et al. Role of MAML1 in targeted therapy against the esophageal cancer stem cells. J Transl Med. 2019;17(1):126.

152. Ma Z, et al. MiR-129-5p inhibits non-small cell lung cancer cell stemness and chemoresistance through targeting DLK1. Biochem Biophys Res Commun. 2017;490(2):309-16.

153. Oishi l, et al. The receptor tyrosine kinase Ror2 is involved in non-canonical Wnt5a/JNK signalling pathway. Genes Cells. 2003;8(7):645-54.

154. Ishitani T, et al. The TAK1-NLK mitogen-activated protein kinase cascade functions in the Wnt-5a/Ca2+ pathway to antagonize Wnt/ $\beta$-catenin signaling. Mol Cell Biol. 2003;23(1):131-9.

155. Topol $\mathrm{L}$, et al. Wnt-5a inhibits the canonical Wnt pathway by promoting GSK-3-independent $\beta$-catenin degradation. J Cell Biol. 2003;162(5):899-908.

156. Hung $\mathrm{T}-\mathrm{H}$, et al. Wnt5A regulates $A B C B 1$ expression in multidrug-resistant cancer cells through activation of the non-canonical PKA/B-catenin pathway. Oncotarget. 2014;5(23):12273.

157. Asem MS, et al. Wnt5a signaling in cancer. Cancers. 2016:8(9):79.

158. Wolff EM, Liang G, Jones PAJNcpU. Mechanisms of disease: genetic and epigenetic alterations that drive bladder cancer. Nat Clin Pract Urol. 2005; 2(10):502-10.

159. Chen $\mathrm{H}$, et al. Evaluation of diagnostic accuracy of DNA methylation biomarkers for bladder cancer: a systematic review and meta-analysis. Biomarkers. 2014;19(3):189-97.

160. Kandimalla R, Van Tilborg AA, Zwarthoff ECJNRU. DNA methylation-based biomarkers in bladder cancer. Nat Rev Urol. 2013;10(6):327.

161. Anglim PP, et al. Identification of a panel of sensitive and specific DNA methylation markers for squamous cell lung cancer. Mol Cancer. 2008;7(1):62

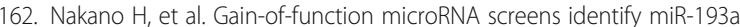
regulating proliferation and apoptosis in epithelial ovarian cancer cells. Int J Oncol. 2013:42(6):1875-82.

163. Li Y, et al. Epigenetic silencing of microRNA-193a contributes to leukemogenesis in $\mathrm{t}(8 ; 21)$ acute myeloid leukemia by activating the PTEN/ PI3K signal pathway. Blood, J Am Soc Hematol. 2013;121(3):499-509.
164. Brunkan AL, Goate AM. Presenilin function and $\gamma$-secretase activity. J Neurochemistry. 2005;93(4):769-92.

165. Cho S, Lu M, He X, Ee PL, Bhat U, Schneider E, Miele L, Beck WT. Notch1 regulates the expression of the multidrug resistance gene ABCC1/MRP1 in cultured cancer cells. Proc Natl Acad Sci. 2011;108(51):20778-83.

166. Balamurugan $K$, Sterneck E. The many faces of C/EBP $\delta$ and their relevance for inflammation and cancer. Int J Biol Sci. 2013;9(9):917.

167. Ko CY, Chang WC, Wang JM. Biological roles of CCAAT/Enhancer-binding protein delta during inflammation. J Biomed Sci. 2015;22(1):6.

168. Pulido-Salgado M, Vidal-Taboada JM, Saura J. C/EBP $\beta$ and C/EBPS transcription factors: basic biology and roles in the CNS. Prog Neurobiol. 2015;132:1-33.

169. Iliopoulos D, Rotem A, Struhl K. Inhibition of miR-193a expression by Max and RXRa activates K-Ras and PLAU to mediate distinct aspects of cellular transformation. Cancer Res. 2011:71(15):5144-53.

170. Gao X, et al. MicroRNA-193a represses c-kit expression and functions as a methylation-silenced tumor suppressor in acute myeloid leukemia. Oncogene. 2011;30(31):3416-28.

171. Han J-W, et al. Genome-wide association study in a Chinese Han population identifies nine new susceptibility loci for systemic lupus erythematosus. Nat Genet. 2009:41(11):1234.

172. Bittel D, et al. Refining the 22q11. 2 deletion breakpoints in DiGeorge syndrome by aCGH. Cytogenet Genome Res. 2009;124(2):113-20.

173. Cazalla D, et al. Nuclear export and retention signals in the RS domain of SR proteins. Mol Cell Biol. 2002;22(19):6871-82.

174. Young TM, et al. The human I-mfa domain-containing protein, HIC, interacts with cyclin T1 and modulates P-TEFb-dependent transcription. Mol Cell Biol. 2003;23(18):6373-84

175. Kanazawa S, et al. c-Myc recruits P-TEFb for transcription, cellular proliferation and apoptosis. Oncogene. 2003;22(36):5707-11.

176. Gregory PA, et al. The miR-200 family and miR-205 regulate epithelial to mesenchymal transition by targeting ZEB1 and SIP1. Nat Cell Biol. 2008; 10(5):593-601.

177. Park S-M, et al. The miR-200 family determines the epithelial phenotype of cancer cells by targeting the E-cadherin repressors ZEB1 and ZEB2. Genes Dev. 2008:22(7):894-907.

178. De Caceres II, et al. IGFBP-3 hypermethylation-derived deficiency mediates cisplatin resistance in non-small-cell lung cancer. Oncogene. 2010;29(11): 1681-90.

179. von Karstedt S, Montinaro A, Walczak HJNRC. Exploring the TRAlLs less travelled: TRAIL in cancer biology and therapy. Nat Rev Cancer. 2017;17(6): 352.

180. Herr HW, et al. Defining optimal therapy for muscle invasive bladder cancer. J Urol. 2007:177(2):437-43.

181. Wang $X$. The expanding role of mitochondria in apoptosis. Genes Dev. 2001;15(22):2922-33.

182. Dohi T, et al. An IAP-IAP complex inhibits apoptosis. J Biol Chem. 2004; 279(33):34087-90.

183. Zhang J, et al. miR-214 promotes apoptosis and sensitizes breast cancer cells to doxorubicin by targeting the RFWD2-p53 cascade. Biochem Biophys Res Commun. 2016;478(1):337-42.

184. Yu X, et al. MiR-214 increases the sensitivity of breast cancer cells to tamoxifen and fulvestrant through inhibition of autophagy. Mol Cancer. 2015;14(1):208

185. Li Q-Q, et al. Sulforaphane inhibits cancer stem-like cell properties and cisplatin resistance through miR-214-mediated downregulation of c-MYC in non-small cell lung cancer. Oncotarget. 2017:8(7):12067.

186. Han G, et al. microRNA-218 inhibits prostate cancer cell growth and promotes apoptosis by repressing TPD52 expression. Biochem Biophys Res Commun. 2015;456(3):804-9.

187. Wang J, et al. MicroRNA-214 suppresses oncogenesis and exerts impact on prognosis by targeting PDRG1 in bladder cancer. Plos One. 2015;10(2).

188. Dasari S, Tchounwou PB. Cisplatin in cancer therapy: molecular mechanisms of action. Eur J Pharmacol. 2014;740:364-78.

189. Galluzzi $L$, et al. Molecular mechanisms of cisplatin resistance. Oncogene. 2012;31(15):1869-83.

190. Moreno-Sánchez R, et al. Energy metabolism in tumor cells. FEBS J. 2007; 274(6):1393-418

191. Wong QW, Ching AK, Chan AW, Choy KW, To KF, Lai PB, Wong N. MiR-222 overexpression confers cell migratory advantages in hepatocellular 
carcinoma through enhancing AKT signaling. Clin Cancer Res. 2010;16(3): 867-75.

192. Gan R, Yang Y, Yang X, Zhao L, Lu J, Meng QH. Downregulation of miR-221/ 222 enhances sensitivity of breast cancer cells to tamoxifen through upregulation of TIMP 3. Cancer Gene Ther. 2014;21(7):290-6.

193. Yang YF, Wang F, Xiao JJ, Song Y, Zhao YY, Cao Y, Bei YH, Yang CQ. MiR222 overexpression promotes proliferation of human hepatocellular carcinoma HepG2 cells by downregulating p27. Int J Clin experimental Med. 2014;7(4):893.

194. Garofalo M, Quintavalle C, Romano G, M croce C, Condorelli G. miR221/222 in cancer: their role in tumor progression and response to therapy. Curr Mol Med. 2012;12(1):27-33

195. SSchönthal AH. Role of serine/threonine protein phosphatase $2 \mathrm{~A}$ in cancer. Cancer Lett. 2001;170(1):1-13.

196. Virshup DM. Protein phosphatase 2A: a panoply of enzymes. Curr Opin Cell Biol. 2000;12(2):180-5.

197. Janssens V, Goris J. Protein phosphatase 2A: a highly regulated family of serine/threonine phosphatases implicated in cell growth and signalling. Biochem J. 2001;353(3):417-39.

\section{Publisher's Note}

Springer Nature remains neutral with regard to jurisdictional claims in published maps and institutional affiliations.

Ready to submit your research? Choose BMC and benefit from:

- fast, convenient online submission

- thorough peer review by experienced researchers in your field

- rapid publication on acceptance

- support for research data, including large and complex data types

- gold Open Access which fosters wider collaboration and increased citations

- maximum visibility for your research: over $100 \mathrm{M}$ website views per year

At BMC, research is always in progress.

Learn more biomedcentral.com/submissions 